\title{
Rosemary Extract as a Potential Anti-Hyperglycemic Agent: Current Evidence and Future Perspectives
}

\author{
Madina Naimi ${ }^{1}$, Filip Vlavcheski ${ }^{1}$, Hesham Shamshoum ${ }^{1}$ and Evangelia Tsiani ${ }^{1,2, *}$ (D) \\ 1 Department of Health Sciences, Brock University, St. Catharines, ON L2S 3A1, Canada; \\ madinanaimi@gmail.com (M.N.); fv11vi@brocku.ca (F.V.); hs12af@brocku.ca (H.S.) \\ 2 Centre for Bone and Muscle Health, Brock University, St. Catharines, ON L2S 3A1, Canada \\ * Correspondence: 1tsiani@brocku.ca; Tel.: +1-905-688-5550 (ext. 3881)
}

Received: 15 August 2017; Accepted: 29 August 2017; Published: 1 September 2017

\begin{abstract}
Type 2 diabetes mellitus (T2DM), a disease on the rise and with huge economic burden to health care systems around the globe, results from defects in insulin action (termed insulin resistance) combined with impaired insulin secretion. Current methods of prevention and treatments for insulin resistance and T2DM are lacking in number and efficacy and, therefore, there is a need for new preventative measures and targeted therapies. In recent years, chemicals found in plants/herbs have attracted attention for their use as functional foods or nutraceuticals for preventing and treating insulin resistance and T2DM. Rosemary is an evergreen shrub indigenous to the Mediterranean region and South America, which contains various polyphenols. Rosemary extract and its polyphenolic constituents have been reported to have antioxidant, anti-inflammatory, anticancer, and anti-hyperglycemic properties. The current review summarizes the existing in vitro and in vivo studies examining the anti-diabetic effects of rosemary extract and its polyphenolic components and highlights the known mechanism of action.
\end{abstract}

Keywords: insulin resistance; diabetes; rosemary extract; rosmarinic acid; carnosic acid; carnosol

\section{Introduction}

Type 2 diabetes mellitus (T2DM) is a disease resulting from impairments in insulin action and insulin secretion [1]. Diminished insulin action and insulin secretion lead to deregulation of glucose and fat metabolism in various tissues including skeletal muscle, adipose tissue and liver and failure to maintain normal blood glucose levels. This prolonged pathological state characterized by hyperglycemia and hyperlipidemia leads to complications such as retinopathy; neuropathy; nephropathy; and microvascular, macrovascular and cardiovascular problems. According to the World Health Organization and the International Diabetes Federation (IDF) estimates, T2DM is rapidly growing and will be affecting more than 439 million adults by 2030 [2]. At present, there is no cure for diabetes mellitus as is true for many of the major chronic diseases inflicting the world's population at large. Current therapeutic strategies for diabetes mellitus are aimed at management and alleviation of the underlying pathological processes and include lifestyle modifications such as healthy diet, weight management and regular physical activity coupled with medication/drug interventions [3].

Oral medications for T2DM treatment include drugs that stimulate insulin release from $\beta$-cells (sulfonylureas and meglitinides); inhibit intestinal glucose absorption ( $\alpha$-glucosidase-inhibitors); increase peripheral glucose transport; and reduce hepatic glucose output through inhibition of gluconeogenesis (biguanides and thiazolidinediones) (Figure 1). Metformin (biguanide) is the most widely used treatment for T2DM; unfortunately, it is associated with increased lactic acid acidosis [4] and $30 \%$ of patients report gastrointestinal problems such as diarrhea, cramps, nausea and vomiting that can lead to discontinuation of the drug [5]. In the last decade, several new drugs for T2DM were 
introduced. Dipeptidyl peptide 4 (DDP-4) inhibitors or gliptins (sitagliptin, saxagliptin, and linagliptin) inhibit glucagon release resulting in reduced blood glucose levels, however significant side effects include increased risk of heart failure, pancreatitis and pancreatic cancer [6]. Moreover, glucagon-like peptide 1 (GLP-1) receptor agonists (lxenatide and liraglutide) stimulate insulin and inhibit glucagon release thereby lowering the blood glucose levels. Although GLP-1 agonists have lower risk of hypoglycemia compared to sulfonylureas and meglitinides, they work in the same pathway as DPP-4 inhibitors and there are concerns of an increased risk of pancreatitis and pancreatic cancer [7]. Oral sodium-glucose cotransporter 2 (SGLT2) inhibitors (canagliflozin and dapagliflozin) are the newest anti-diabetic drugs, and work by endorsing urinary glucose excretion and inhibiting renal glucose reabsorption. Although they show promising results for T2DM therapy, their side-effects may include severe urinary tract infections, ketoacidosis and hypotension $[8,9]$.

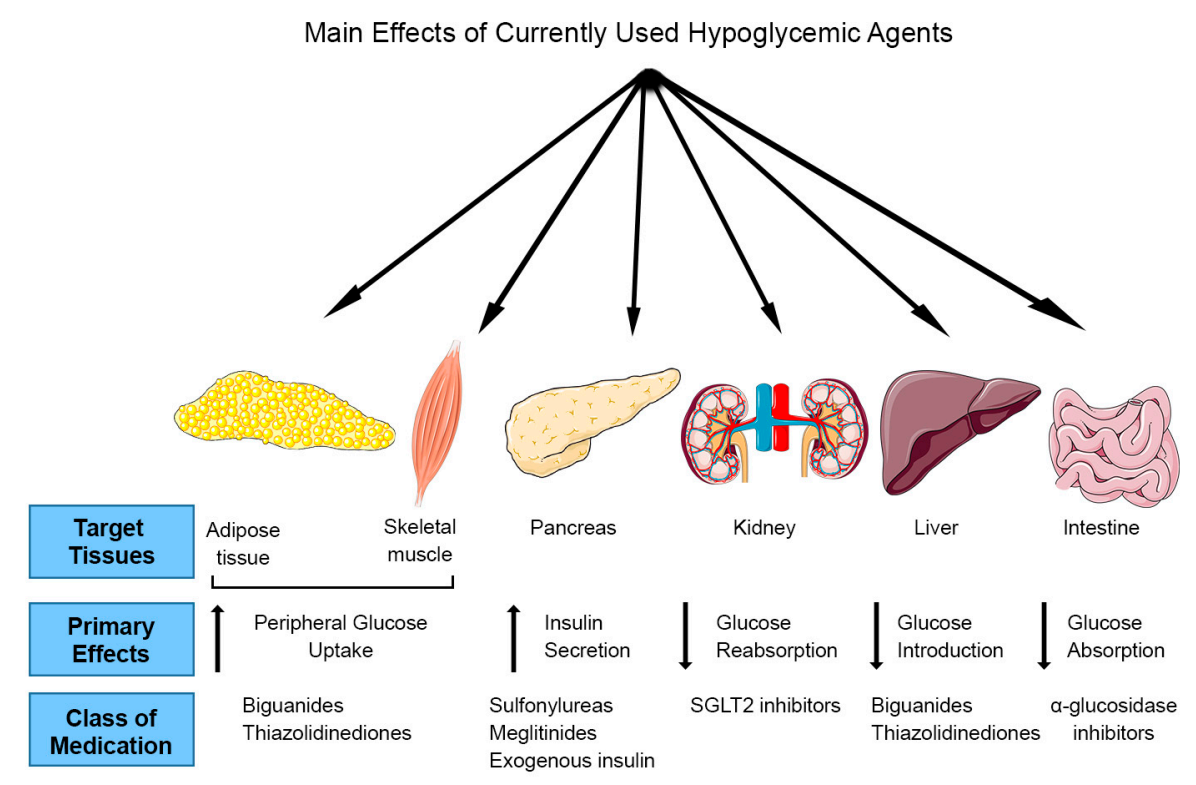

Figure 1. Target tissues and mechanism of action of current anti-diabetic drugs.

Overall, there is a continued interest to find more effective drugs with less side effects. On the other hand, despite the availability of various compounds to manage T2DM, the disease is a global health problem with $50 \%$ of the affected individuals living in poverty stricken areas in Africa and Asia and therefore there is an urgent need to find effective but less expensive medicine. The study of novel compounds that can exert an insulin-like effect, increase insulin sensitivity and even improve efficacy of existing medication at lower doses and reduce their adverse effects is highly desired and they will widen the spectrum of preventative and treatment options for insulin resistance and T2DM.

The use of plants for healing purposes predates recording history and forms the origin of much of modern medicine [10]. Phytotherapy is still the mainstay of about $75-80 \%$ of the world's population centralized in developing countries for primary health care. Notably, in the last few years, there has been a major rise in phytotherapy in the developed world. In Germany and France, many herbs and herbal extracts are used as prescription drugs and their sales in the countries of the European Union were around 6 billion in 1991 and might be over 20 billion dollars now [10,11].

Many conventional drugs originate from plant sources including aspirin (from willow tree bark), digoxin (from foxglove), quinine (from cinchona bark), and morphine (from the opium poppy). Prior to and after the discovery of insulin, herbs with hypoglycemic effects have been used in folk medicine and are still prevalent. As evidence of this concept, metformin, which is the first line of treatment for T2DM, was purified from the French lilac Galega officinalis L. 
The development of drugs from plants continues, with drug companies engaged in large-scale pharmacologic screening of various plants including herbs. Any part of a plant, including leaves, stems, flowers, roots, and seeds can be formulated as raw material or extracts. Maceration of plants with water, alcohol or other solvents results in extraction of their active pharmaceutical ingredients including fatty acids, sterols, alkaloids, polyphenols, glycosides, saponins, and others [10]. Recently, a web server (http:/ / bio-hpc.eu/dia-db) has been established that can be used to predict diabetes-related bioactive compounds. The prediction is accomplished by: (1) inverse virtual screening of the input molecule chosen by the user against a set of protein targets identified as key elements in diabetes; and (2) by comparing it to the database of anti-diabetic drugs. This website could be utilized in plant extracts to explore the anti-diabetic potential of specific phytochemical contents of the extract.

\section{Phenolic Compounds of Rosemary}

Rosemary (Rosmarinus officinalis L.) is an aromatic, evergreen shrub plant belonging to the labiatae family (Lamiaceae) and indigenous to the Mediterranean region and South America [12-16]. The fresh and dried leaves have been extensively used as seasoning as well as in traditional medicine [16]. Historically, rosemary has been used medicinally to treat renal colic and dysmenorrhea, stimulate hair growth and relieve symptoms caused by respiratory disorders $[12,14,17]$. Today, rosemary extract is often used in aromatherapy to treat anxiety-related conditions and increase alertness [15,17].

Formulations of rosemary include the raw leaves, and extracts of rosemary. Conventional extraction methods such as hydrodistillation, decoction and maceration along with other methods including pressurized liquid extract, enzyme-assisted extraction, nanofiltration and solid-phase extraction have been employed to extract polyphenols from plant materials [10,18].

Rosemary extract (RE) contains different classes of polyphenols including phenolic acids, flavonoids and phenolic terpenes [18-22] (Table 1). Phenolic acids include: (a) the hydroxycinnamic acids: rosmarinic acid, chlorogenic acid, p-coumaric acid, m-hydroxybenzoic acid, coumaroylquinic acid, ferulic acid and coumaric acid; (b) the hydroxybenzoic acids: vanillic acid, syringic acid, caffeic acid, protocatechuic acid, dicaffeoylquinic; acid and (c) the hydroxyphenylacetic acids: homovanillic acid and p-hydroxybenzoic acid. Flavonoids include the flavones: apigenin, luteolin, hispidulin and genkwanin. In addition, they include the flavonols: rutin, kaempferol, kaempferol-3-O-rutinoside, naringenin- $C$-hexoside, hesperetin, apigenin-7-O-glucoside, quercetin, isorhamnetin-3-O-hexoside, apigenin-acetylglucosidase, isohamnetin-lutelion, and isorhamnetin-luteolin [18,21,22]. Phenolic terpenes found in rosemary include diterpenes such as carnosol, carnosic acid, rosmanol, epirosmanol, isorosmanol, rosemaridiphenol, rosmadial, Methoxycarnosol and Methoxycarnosate [18,21,22]. In addition, triterprnres such as betulinic acid, oleanolic acid, and ursolic acid (Table 1) [23,24].

The polyphenols found in highest quantity in RE are carnosic acid (CA), carnosol $(\mathrm{COH})$ and rosmarinic acid (RA) (Figure 2) [22,25] and their production is influenced by growth conditions such as sunlight exposure, soil quality, and water availability [10]. Furthermore, anatomical regions of this herbal plant have varying levels of total phenolic content whereby the leaves contain the highest concentration of polyphenols in comparison to stem, branch and flower regions [26]. On the other hand, the choice of solvent and extraction method affects the chemical composition of the extract with the possibility of losing lipid soluble chemicals by an aqueous-based extraction method and water soluble chemicals by nonpolar solvent (ethanol, methanol)-based extraction. Regardless of the extraction method used, RE has been shown to have antioxidant, anti-inflammatory, anti-microbial, anti-tumorigenic, and anti-hyperglycemic properties. These biological effects are highly correlated with the polyphenolic content and $\mathrm{CA}, \mathrm{COH}$ and RA are suggested to be responsible. The present review focuses on the existing studies examining the anti-diabetic effects of RE. Studies examining the anti-diabetic properties of $\mathrm{CA}, \mathrm{COH}$ and $\mathrm{RA}$ are also included. In the following sections, in vitro and in vivo animal and human studies are presented. 
Table 1. Polyphenolic profile of Rosemary extract (RE).

\begin{tabular}{|c|c|c|c|c|c|c|}
\hline \multicolumn{7}{|c|}{ Polyphenols } \\
\hline \multicolumn{3}{|c|}{ Phenolic Acids } & \multicolumn{2}{|c|}{ Flavonoids } & \multicolumn{2}{|c|}{ Phenolic Terpenes } \\
\hline $\begin{array}{l}\text { Hydroxycinnamic } \\
\text { Acids }\end{array}$ & $\begin{array}{l}\text { Hydroxybenzoic } \\
\text { Acids }\end{array}$ & $\begin{array}{l}\text { Hydroxyphenylacetic } \\
\text { Acids }\end{array}$ & Flavones & Flavonols & Diterpenes & Triterprnres \\
\hline $\begin{array}{l}\text { Rosmarinic acid } \\
\left(\mathrm{C}_{18} \mathrm{H}_{16} \mathrm{O}_{8}\right)[18]\end{array}$ & $\begin{array}{c}\text { Vanillic acid } \\
\left(\mathrm{C}_{8} \mathrm{H}_{18} \mathrm{O}_{4}\right)[22] \\
\end{array}$ & $\begin{array}{l}\text { Homovanillic acid } \\
\left(\mathrm{C}_{9} \mathrm{H}_{10} \mathrm{O}_{4}\right)[22]\end{array}$ & $\begin{array}{c}\text { Apigenin } \\
\left(\mathrm{C}_{27} \mathrm{H}_{30} \mathrm{O}_{15}\right)[18] \\
\end{array}$ & Rutin $\left(\mathrm{C}_{27} \mathrm{H}_{30} \mathrm{O}_{16}\right)[18]$ & $\begin{array}{c}\text { Carnosol }\left(\mathrm{C}_{20} \mathrm{H}_{26} \mathrm{O}_{4}\right) \\
{[18,21,22]}\end{array}$ & $\begin{array}{c}\text { Betulinic acid } \\
\left(\mathrm{C}_{30} \mathrm{H}_{48} \mathrm{O}_{3}\right)[23,24]\end{array}$ \\
\hline $\begin{array}{c}\text { Chlorogenic acid } \\
\left(\mathrm{C}_{16} \mathrm{H}_{18} \mathrm{O}_{9}\right)[18,21,22]\end{array}$ & $\begin{array}{c}\text { Syringic acid } \\
\left(\mathrm{C}_{9} \mathrm{H}_{10} \mathrm{O}_{5}\right)[18,21,22] \\
\end{array}$ & $\begin{array}{l}\text { p-Hydroxybenzoic } \\
\text { acid }\left(\mathrm{C}_{7} \mathrm{H}_{6} \mathrm{O}_{3}\right)[22]\end{array}$ & $\begin{array}{c}\text { Luteolin }\left(\mathrm{C}_{15} \mathrm{H}_{10} \mathrm{O}_{6}\right) \\
{[18]}\end{array}$ & $\begin{array}{c}\text { Kaempferol }\left(\mathrm{C}_{15} \mathrm{H}_{10} \mathrm{O}_{6}\right) \\
{[18,21,22]}\end{array}$ & $\begin{array}{c}\text { Carnosic acid } \\
\left(\mathrm{C}_{20} \mathrm{H}_{28} \mathrm{O}_{4}\right)[18,21,22] \\
\end{array}$ & $\begin{array}{c}\text { Oleanolic acid } \\
\left(\mathrm{C}_{30} \mathrm{H}_{48} \mathrm{O}_{3}\right)[23,24] \\
\end{array}$ \\
\hline $\begin{array}{c}\text { o-,m-,p-Coumaric } \\
\text { acid }\left(\mathrm{C}_{9} \mathrm{H}_{8} \mathrm{O}_{3}\right) \\
{[18,21,22]} \\
\end{array}$ & $\begin{array}{c}\text { Caffeic acid }\left(\mathrm{C}_{9} \mathrm{H}_{7} \mathrm{O}_{4}\right) \\
{[18,21,22]}\end{array}$ & & $\begin{array}{c}\text { Hispidulin } \\
\left(\mathrm{C}_{16} \mathrm{H}_{12} \mathrm{O}_{6}\right)[23,24]\end{array}$ & $\begin{array}{l}\text { Kaempferol-3-O-rutinoside } \\
\left(\mathrm{C}_{27} \mathrm{H}_{30} \mathrm{O}_{15}\right)[18,21,22]\end{array}$ & $\begin{array}{c}\text { Rosmanol }\left(\mathrm{C}_{20} \mathrm{H}_{26} \mathrm{O}_{5}\right) \\
{[18,21,22]}\end{array}$ & $\begin{array}{c}\text { Ursolic acid } \\
\left(\mathrm{C}_{30} \mathrm{H}_{48} \mathrm{O}_{3}\right)[23,24]\end{array}$ \\
\hline $\begin{array}{c}\text { m-Hydroxybenzoic } \\
\text { acid }\left(\mathrm{C}_{7} \mathrm{H}_{6} \mathrm{O}_{3}\right) \\
{[18,21,22]}\end{array}$ & $\begin{array}{l}\text { Protocatechuic acid } \\
\left(\mathrm{C}_{7} \mathrm{H}_{6} \mathrm{O}_{4}\right)[18,21,22]\end{array}$ & & $\begin{array}{c}\text { Genkwanin } \\
\left(\mathrm{C}_{16} \mathrm{H}_{12} \mathrm{O}_{5}\right)[23,24]\end{array}$ & $\begin{array}{l}\text { Naringenin- } C \text {-hexoside } \\
\qquad\left(\mathrm{C}_{21} \mathrm{H}_{22} \mathrm{O}_{10}\right)[21,22]\end{array}$ & $\begin{array}{c}\text { Epirosmanol }\left(\mathrm{C}_{20} \mathrm{H}_{26} \mathrm{O}_{5}\right) \\
{[21,22]}\end{array}$ & \\
\hline $\begin{array}{l}\text { Coumaroylqunic acid } \\
\left(\mathrm{C}_{16} \mathrm{H}_{18} \mathrm{O}_{8}\right)[21,22]\end{array}$ & $\begin{array}{c}\text { Dicaffeoylquinic acid } \\
\left(\mathrm{C}_{25} \mathrm{H}_{24} \mathrm{O}_{12}\right) \\
{[18,21,22]}\end{array}$ & & & $\begin{array}{c}\text { Hesperetin }\left(\mathrm{C}_{28} \mathrm{H}_{34} \mathrm{O}_{15}\right) \\
{[18]}\end{array}$ & $\begin{array}{c}\text { Isorosmanol }\left(\mathrm{C}_{20} \mathrm{H}_{26} \mathrm{O}_{5}\right) \\
{[18,21,22]}\end{array}$ & \\
\hline \multirow[t]{6}{*}{$\begin{array}{c}\text { Ferulic acid } \\
\left(\mathrm{C}_{16} \mathrm{H}_{20} \mathrm{O}_{9}\right)[21,22]\end{array}$} & & & & $\begin{array}{l}\text { Apigenin-7-O-glucoside } \\
\left(\mathrm{C}_{21} \mathrm{H}_{20} \mathrm{O}_{10}\right)[18]\end{array}$ & $\begin{array}{c}\text { Rosmaridiphenol } \\
\left(\mathrm{C}_{20} \mathrm{H}_{28} \mathrm{O}_{3}\right)[18] \\
\end{array}$ & \\
\hline & & & & Quercetin $\left(\mathrm{C}_{15} \mathrm{H}_{10} \mathrm{O}_{7}\right)[18]$ & $\begin{array}{c}\text { Rosmadial }\left(\mathrm{C}_{20} \mathrm{H}_{24} \mathrm{O}_{5}\right) \\
{[18]}\end{array}$ & \\
\hline & & & & $\begin{array}{l}\text { Isorhamnetin-3-O-hexoside } \\
\quad\left(\mathrm{C}_{22} \mathrm{H}_{22} \mathrm{O}_{12}\right)[23,24]\end{array}$ & Methoxycarnosol $[23,24]$ & \\
\hline & & & & $\begin{array}{c}\text { Apigenin-acetylglucosidase } \\
{[23,24]}\end{array}$ & $\begin{array}{c}\text { Methoxycarnosate } \\
{[23,24]} \\
\end{array}$ & \\
\hline & & & & Isohamnetin-lutelion $[23,24]$ & & \\
\hline & & & & $\begin{array}{c}\text { Isorhamnetin-luteolin } \\
{[23,24]}\end{array}$ & & \\
\hline
\end{tabular}


<smiles>CC(C)c1cc2c(c(O)c1O)[C@@]1(O)CCCC(C)(C)[C@@H]1CC2</smiles>

Carnosic Acid<smiles>O=C(/C=C/c1ccc(O)c(O)c1)OC(Cc1ccc(O)c(O)c1)C(=O)O</smiles>

Rosmarinic Acid<smiles>CC(C)c1cc2c(c(O)c1O)C13CCCC(C)(C)C1CC(O2)C3=O</smiles>

Carnosol

Figure 2. Structure of the major polyphenols of Rosmarinus officinalis: Carnosic acid, Rosmarinic acid and Carnosol.

\section{Evidence of Anti-Diabetic Effects of Rosemary Extract: In Vitro Studies (Cell Free Models)}

Digestive enzymes convert starch to maltose and iso-maltose which then travel to the small intestine where they are converted along with sucrose to monosaccharides (glucose and fructose) by $\alpha$-glucosidase (sucrase and maltase) and transported by the intestinal sodium-glucose cotransporter thereby increasing blood glucose levels [27]. Inhibitors of $\alpha$-glucosidase are used in the management of hyperglycemia present in T2DM. Acarbose is a currently prescribed anti-diabetic drug that reduces the rate of glucose absorption through inhibition of $\alpha$-glucosidase in the brush border of the small intestine and pancreatic $\alpha$-amylase found in the lumen of the small intestine [27]. RE exposure $(5.5 \mathrm{mg} / \mathrm{mL}-55 \mathrm{mg} / \mathrm{mL}$ ) was found to have significant $\alpha$-glucosidase inhibitory activity (60\% decrease) [28], while, in another study, the $\mathrm{IC}_{50}$ was found to be $683-711 \mu \mathrm{g} / \mathrm{mL}$, making RE extract the most potent among 31 other extracts of herbs and spices tested [29] (Table 2). Furthermore, RA $(8.88 \mathrm{mM})$ was also demonstrated to significantly inhibit porcine pancreatic amylase activity [30].

$\mathrm{RE}$ was found to be a potent inhibitor of DPP-IV $\left(\mathrm{IC}_{50}\right.$ of $6.5 \pm 0.4 \mu \mathrm{M}$ gallic acid equivalents (GAE)) comparable to sitagliptin $(0.05 \pm 0.01 \mu \mathrm{M})$ [31]. Computational modeling experiments demonstrated that carnosol found in highest levels in RE had a strong binding affinity to DPP-IV [31].

The breakdown of triglycerides is regulated by lipases such as hormone-sensitive lipase (HSL) in adipose tissue and pancreatic lipase (PL) in the lumen of the small intestines. Excessive activation of hormone sensitive lipase leads to increased serum levels of free fatty acids (FFA) and insulin inhibits this hormone [32]. RE at concentrations of $6.3-200 \mu \mathrm{g} / \mathrm{mL}$ had a dose-dependent inhibitory activity ranging from $2.4-64.9 \%$ for HSL and $36.8-95.1 \%$ for PL effects that were less potent but in the same direction as orlistat, an FDA approved anti-obesity drug [33]. Pure RA was also shown to inhibit HSL and PL in a dose dependent manner although the degree of inhibition was lower than the whole extract [33]. Additionally, in vitro analysis indicated that CA enriched rosemary extract $(100 \mu \mathrm{g} / \mathrm{mL})$ inhibited PL activity by $70 \%$ [34]. COH, a major RE constituent, was found to have potent inhibitory activity $\left(\mathrm{IC}_{50}=62.5 \mu \mathrm{M}\right)$ against rat liver diacylglycerol acyltransferase 1 (DGAT1), an enzyme that plays a fundamental role in triglyceride synthesis [35]. $\mathrm{COH}(20 \mu \mathrm{M}, 40 \mu \mathrm{M})$ was found to inhibit intracellular de novo triglyceride synthesis by $67.5-90.6 \%$ without affecting cell viability [35]. These studies clearly indicate that similar to the action of insulin, rosemary, CA and RA have antilipolytic activity in vitro. 
Table 2. Anti-diabetic Effects of Rosemary Extract and its Main Polyphenolic Constituents: cell-free model studies.

\begin{tabular}{|c|c|c|c|}
\hline Cell-Free Model & Dose & Effects & Reference \\
\hline$\alpha$-glycosidase & $\mathrm{RE} 5.5-55 \mathrm{mg} / \mathrm{mL}$ & $\downarrow \alpha$-glycosidase activity (60\%) & [28] \\
\hline$\alpha$-glycosidase & $\begin{array}{c}50 \% \text { ethanolic RE } \\
\left(\mathrm{IC}_{50}: 83-711 \mu \mathrm{g} / \mathrm{mL}\right)\end{array}$ & $\downarrow \alpha$-glucosidase & [29] \\
\hline Porcine Pancreatic $\alpha$-amylase (PPAM) & RA $8.88 \mathrm{mM}$ & $\downarrow$ PPAM activity (85\%) & [30] \\
\hline $\begin{array}{l}\text { Dipeptidyl Peptidase IV (DPP-IV); Protein } \\
\text { Tyrosine Phosphatase 1B (PTP1B) }\end{array}$ & $\begin{array}{c}\text { Methanolic RE } \\
\left(\mathrm{IC}_{50}=6.5 \pm 0.4 \mu \mathrm{M}\right) \\
\mathrm{RA}\left(\mathrm{IC}_{50}=14.1 \pm 1.7 \mu \mathrm{M}\right) \\
\mathrm{COH}\left(\mathrm{IC}_{50}>100 \mu \mathrm{M}\right)\end{array}$ & $\begin{array}{c}\downarrow \text { DPP-IV activity }(50 \%) \\
\text { RE }(\downarrow \text { PTP1B } 40.9 \pm 7.2 \%) .\end{array}$ & [31] \\
\hline $\begin{array}{c}\text { Porcine pancreatic lipase (PL); Hormone } \\
\text { sensitive lipase (HSL) }\end{array}$ & $\begin{array}{c}\text { Methanolic RE } 6.3-200 \mu \mathrm{g} / \mathrm{mL} \\
\text { RE }\left(\mathrm{IC}_{50}=13.8 \text { for PL and }\right. \\
95.2 \mu \mathrm{g} / \mathrm{mL} \text { for HSL) } \\
\text { RA (IC } \mathrm{I}_{50}=125.2 \text { for PL and } \\
51.5 \mu \mathrm{g} / \mathrm{mL} \text { for HSL) }\end{array}$ & $\begin{array}{c}\downarrow \text { PL and HSL activity } \\
\text { RE }(\downarrow \text { PL: } 36.8-95.1 \%) \\
\text { RE }(\downarrow \text { HSL: } 2.4-64.9 \%) \\
\text { RE > RA }\end{array}$ & [33] \\
\hline Human PL & Acetone RE $100 \mu \mathrm{g} / \mathrm{mL}$ rich in CA & $\downarrow$ human PL $(70 \%)$ & [34] \\
\hline $\begin{array}{l}\text { Rat liver diacylglycerol acyltransferase } \\
\text { (DGAT1) }\end{array}$ & $\mathrm{COH}\left(\mathrm{IC}_{50}=62.5 \pm 2.1 \mu \mathrm{M}\right)$ & $\begin{array}{l}\downarrow \text { DGAT1 activity } \\
\quad(67.5-90.6 \%)\end{array}$ & [35] \\
\hline
\end{tabular}

\section{Evidence of Anti-Diabetic Effects of Rosemary Extract: In Vitro Studies (Hepatocytes)}

In vitro studies have shown that RE $(100 \mu \mathrm{g} / \mathrm{mL})$ has an insulin-like effect to inhibit the production of glucose by hepatocytes. RE was shown to significantly suppress gluconeogenesis in HepG2 hepatocytes (Table 3) [36]. In another study, RE (2.0-50 $\mathrm{g} / \mathrm{mL})$ was shown to significantly increase hepatocyte (HepG2) glucose consumption in a dose-dependent manner (6\% to $21 \%$ ) [37]. In addition, a significant decrease in cellular glycogen content and increase glycolytic rate was seen [37]. CA (10-20 mM), a major polyphenolic constituent of RE, prevented palmitate-induced lipid accumulation in hepatocytes [38] indicating that CA may potentially block cellular lipid accumulation in the long term and help against insulin resistance and T2DM. Furthermore, it was found that treatment of HepG2 hepatocytes with $\mathrm{COH}(20-40 \mu \mathrm{M})$ resulted in inhibition of intracellular triglyceride synthesis via an effect that was associated with significant inhibition of diacylglycerol acyltransferase (DGAT1), the enzyme that plays a pivotal role in catalyzing the formation of triglycerides from Acetyl-CoA and diacylglycerol [35]. It is important to note that inhibition of DAGT1 has been proposed as a target approach for T2DM and obesity treatment. RE's polyphenolic constituents may also provide protection against chemically-induced reactive oxygen species production and hepatocyte death. RA exhibited significant cytoprotective effects against mycotoxin-induced reactive oxygen species (ROS) production and induction of apoptosis by blocking effects on caspase-3 activation in hepatocytes [39].

Table 3. Anti-diabetic Effects of Rosemary Extract and its Main Polyphenolic Constituents: in vitro studies (hepatocytes).

\begin{tabular}{|c|c|c|c|}
\hline Cell/Model & Treatment & Effects & Reference \\
\hline HepG2 hepatocytes & $\begin{array}{l}\text { Methanolic RE } \\
100 \mu \mathrm{g} / \mathrm{mL}\end{array}$ & $\downarrow$ gluconeogenesis & [36] \\
\hline HepG2 hepatocytes & $\begin{array}{l}\text { Methanolic RE } 0.4,2,10 \\
50 \mu \mathrm{g} / \mathrm{mL}\end{array}$ & $\begin{array}{c}\uparrow \text { glucose consumption } \\
\uparrow \text { glycolytic rate } \\
\downarrow \text { glycogenesis comparable to metformin } \\
\uparrow \beta \text {-oxidation } \\
\downarrow \text { decreased fatty acid synthesis } \\
\leftrightarrow \text { cell viability }\end{array}$ & [37] \\
\hline HepG2 hepatocytes & CA $10-20 \mu \mathrm{M}$ & $\begin{array}{l}\downarrow \text { palmitate-induced lipid accumulation } \\
\qquad \text { cell viability }\end{array}$ & [36] \\
\hline HepG2 hepatocytes & COH $20-40 \mu \mathrm{M}$ & $\begin{array}{l}\downarrow \text { de novo formation of intracellular TG } \\
\qquad \leftrightarrow \text { cell viability }\end{array}$ & [35] \\
\hline HepG2 hepatocytes & RA $25-50 \mu \mathrm{M}$ & $\begin{array}{c}\downarrow \text { apoptosis } \\
\downarrow \text { ROS production }\end{array}$ & [39] \\
\hline
\end{tabular}




\section{Evidence of Anti-Diabetic Effects of Rosemary Extract: In Vitro Studies (Adipocytes)}

Treatment of 3T3-L1 adipocytes with CA $(3 \mu \mathrm{M})$ and $\mathrm{COH}(3 \mu \mathrm{M})$ inhibited the differentiation of 3T3-L1 pre-adipocytes into mature adipocytes and increased intracellular glutathione (GSH), an important antioxidant that prevents against ROS-induced damage (Table 4) [40]. Similarly, rosemary extract and CA were demonstrated to inhibit 3T3-L1 adipocyte differentiation, in part through inhibition of the transcription factor PPAR $\gamma$ [41] (Table 4). An increase in glucose uptake and intracellular lipid levels was seen in 3T3-L1 adipocytes treated with RE (50 $\mu \mathrm{g} / \mathrm{mL})$ (Table 4) [42].

Table 4. Anti-diabetic Effects of Rosemary Extract and its Main Polyphenolic Constituents: in vitro studies (adipocytes).

\begin{tabular}{|c|c|c|c|}
\hline Cell & Treatment & Effects & Reference \\
\hline 3T3-L1 adipocytes & $\mathrm{CA} 3 \mu \mathrm{M}, \mathrm{COH} 3 \mu \mathrm{M}$ & $\begin{array}{c}\downarrow \text { differentiation } \\
\uparrow \text { intracellular GSH }\end{array}$ & [40] \\
\hline 3T3-L1 adipocytes & $\begin{array}{l}\text { Acetone RE } 10-30 \mu \mathrm{g} / \mathrm{mL} \\
\text { CA } 0.3-20 \mu \mathrm{M}\end{array}$ & $\begin{array}{l}\text { Inhibited adipocyte differentiation } \\
\qquad \leftrightarrow \text { cell viability }\end{array}$ & [41] \\
\hline 3T3-L1 adipocytes & RE $50 \mu \mathrm{g} / \mathrm{mL}$ & $\begin{array}{l}\uparrow \text { intracellular lipid } \\
\uparrow \text { glucose uptake }\end{array}$ & [42] \\
\hline 3T3-L1 adipocytes & CA $0.1-10 \mu \mathrm{M}$ & $\begin{array}{c}\downarrow \text { intracellular lipid accumulation } \\
\downarrow \text { TG content }(15.5-39.8 \%) \\
\downarrow \text { GPDH activity } \\
\leftrightarrow \text { cell viability }\end{array}$ & [43] \\
\hline $\begin{array}{l}\text { 3T3-L1 adipocytes } \\
\text { pretreated with LPS }\end{array}$ & CA $0-20 \mu \mathrm{M}$ & $\begin{aligned} \downarrow \text { mRNA expression of TNF } \alpha, \text { IL-6 and MCP-1 } \\
\\
\quad \downarrow \text { TLR4 protein expression } \\
\quad \downarrow \text { Phospho-ERK levels } \\
\quad \downarrow \text { NF- } \mathrm{B} \text { B activation }\end{aligned}$ & [44] \\
\hline
\end{tabular}

In contrast, treatment with CA $(0.1-10 \mu \mathrm{M})$ resulted in reduced intracellular lipid accumulation (19.1-33.4\%), TG content (15.5-39.8\%) and glycerol-3-phosphate dehydrogenase (GPDH) activity in 3T3-L1 adipocytes [43]. The activity of cytosolic GPDH, a key regulatory enzyme involved in triglyceride synthesis, dose-dependently decreased in CA treated adipocytes [43].

Corroborating with the above findings, CA significantly decreased mRNA expression of PPAR $\gamma, C / E B P \alpha$ and SREBP1 indicating that it affects PPAR $\gamma /$ SREBP1 medicated adipogenesis [43]. Interestingly, CA treated adipocytes had a lower monounsaturated fatty acid (MUFA) to saturated fatty acid (SFA) ratio compared to control cells which was associated with a reduction of both mRNA and protein expression levels of stearoyl-CoA desaturase 1 (SCD1), a PPAR $\gamma$ dependent enzyme responsible for conversion of SFA to MUFA. MUFAs function as the major substrates for the synthesis of triglycerides and cellular membrane phospholipids in adipocytes, and an increased ratio of MUFA: SFA is correlated with de novo lipogenesis (Table 4) [43].

Carnosic acid treatment (1-20 uM) prevented LPS-stimulated elevations in the mRNA expression of tumor necrosis factor- $\alpha$ (TNF $\alpha$ ), interleukin-6 (IL-6), and monocyte chemoattractant protein-1 (MCP-1) indicating a significant reduction in the inflammatory response of adipocytes [44].

Together, these findings suggest effects of RE and RE polyphenols on adipocyte lipid accumulation and anti-inflammatory effects.

\section{Evidence of Anti-Diabetic Effects of Rosemary Extract: In Vitro Studies (Skeletal Muscle Cells)}

Skeletal muscle tissue is important target of insulin and accounts for approximately $80 \%$ of insulin mediated glucose uptake in the postprandial state. As a consequence, it plays a predominant role in glucose homeostasis. Treatment of L6 myotubes with RE increased glucose uptake in a dose and time dependent manner [45]. Maximum stimulation seen with $5 \mu \mathrm{g} / \mathrm{mL}$ of RE was comparable to maximum stimulation seen with insulin (100 $\mathrm{nM})$ and metformin $(2 \mathrm{mM})$ (Table 5) [45]. 
Table 5. Anti-diabetic Effects of Rosemary Extract and its Main Polyphenolic Constituents: in vitro studies (muscle cells).

\begin{tabular}{|c|c|c|c|}
\hline Cell/Model & Treatment & Effects & Reference \\
\hline L6 myotubes & $\begin{array}{l}\text { Methanolic RE } \\
0.1-50 \mu \mathrm{g} / \mathrm{mL}\end{array}$ & $\begin{array}{l}\uparrow \text { glucose uptake (GU) dose- } \\
\text { and time-dependent } \\
\text { Max stimulation: } 5 \mu \mathrm{g} / \mathrm{mL} \text { for } 4 \mathrm{~h} \\
\text { comparable to insulin and metformin. } \\
\leftrightarrow \text { cell viability }\end{array}$ & [45] \\
\hline L6 myotubes & CA $1-50 \mu \mathrm{M}$ & $\begin{array}{c}\uparrow \mathrm{GU} \text { in a dose- and time-dependent manner } \\
\text { Max stimulation: } 20 \mu \mathrm{M} \text { for } 6 \mathrm{~h} \text { comparable to } \\
\text { insulin and metformin } \\
\leftrightarrow \text { cell viability }\end{array}$ & [46] \\
\hline L6 myotubes & $\begin{array}{c}\text { Methanolic CA } \\
0.1-10 \mu \mathrm{M}\end{array}$ & $\begin{array}{c}\uparrow \mathrm{GU} \text { dose- and time-dependent } \\
\text { Max stimulation: } 2 \mu \mathrm{M} \text { for } 4 \mathrm{~h} \text { comparable } \\
\text { to insulin and metformin } \\
\leftrightarrow \text { cell viability }\end{array}$ & [47] \\
\hline
\end{tabular}

In addition, treatment of $\mathrm{L} 6$ myotubes with CA $(20 \mu \mathrm{g} / \mathrm{mL}$ for $6 \mathrm{~h})$ resulted in significant increase in glucose uptake [46]. Furthermore, in another study by Naimi et al., 2016, CA significantly increased the glucose uptake in a dose- and time-dependent manner with concentration as low as $2 \mu \mathrm{M} C \mathrm{~A}$ [47]. As proof-of-concept, the studies suggest that RE and its components increase skeletal muscle glucose uptake (rate-limiting step in skeletal muscle glucose metabolism) although other potential effects downstream of glucose uptake in this tissue remain to be explored.

All of the above in vitro studies indicate that RE has the potential to affect key insulin target tissues (liver, fat, and muscle) and directly induce anti-diabetic effects.

\section{Evidence of Anti-Diabetic Effects of Rosemary Extract: In Vivo Animal Studies}

Anti-hyperglycemic effects of rosemary and its components have been evaluated in different animal models of T2DM. Experimental interventions such as chemical (streptozotocin and alloxan) and dietary (high fat and high fructose diets) modifications have been employed to induce T2DM in animal models to study the effects of rosemary on associated biomarkers. Due to the lack of standardized pharmacological and clinical evidence, the formulations and doses of rosemary and its components used in these animal studies are variable. Notably, rosemary has not been extensively evaluated in clinical trials involving humans. Collectively, the current in vivo models demonstrate that rosemary and its main components $\mathrm{CA}$ and RA possess significant in vivo anti-hyperglycemic and anti-hyperlipidemic properties as outlined below.

\section{Streptozotocin (STZ)-Induced Diabetes Model}

Streptozotocin (STZ) is traditionally used to induce both type 1 and type 2 diabetes mellitus by promoting $\beta$-cell death through alkylation of DNA [48]. While a high dose of STZ potently impairs insulin secretion mimicking type 1 diabetes, low doses are known to induce a mild impairment of insulin secretion resembling the clinical features of T2DM. The reported studies reciprocally utilize low dose STZ to study the acute and chronic effects of rosemary and its polyphenolic constituents.

In streptozotocin (STZ)-induced diabetic mice, administration of an aqueous RE (10 g/L) for three months resulted in significant decrease in fasting plasma glucose (FPG) level (Table 6) [49]. There were no changes in alkaline phosphatase activity, bilirubin, and creatine indicating that rosemary did not cause cytotoxicity and histotoxicity [49]. In another study, administration of 50\% ethanol extract of rosemary $(20 \mathrm{mg} / \mathrm{kg} /$ day) in STZ rats significantly decreased plasma glucose levels due to inhibition of intestinal glucosidase enzyme activity [29]. In a more recent study, daily administration of aqueous RE ( $200 \mathrm{mg} / \mathrm{kg}$ /day) for three weeks caused significant reductions in blood glucose levels of both normal and STZ-induced diabetic rats [50]. These effects were associated with increased serum catalase (CAT), 
superoxide dismutase (SOD), glutathione peroxidase (GPx), vitamin C and vitamin G, while decreased lipid peroxidation marker MDA levels [50]. Similar effects were seen on blood glucose levels in STZ-induced diabetic rats given aqueous RE $(1.11 \mathrm{~g} / \mathrm{mL})$ for four weeks [51]. In addition, the extract significantly reduced plasmatic FPG, TG, TC and low density lipoprotein (LDL) while increasing high density lipoprotein (HDL) and erythrocytes levels [51]. In agreement with the above studies, the fasting plasma blood glucose levels as well as TC, LDL and TG levels were significantly reduced while HDL was increased in STZ-induced diabetic rats given aqueous RE (200 mg/ kg/day) two weeks before and three weeks after STZ injection [52]. Administration of aqueous RE (200 mg/ $\mathrm{kg} / \mathrm{day})$ for 21 days in STZ-induced diabetic rats resulted in decrease in FPG, TC and total antioxidant capacity [53]. Furthermore, administration of aqueous RE (200 mg/kg/day) for four weeks prior and to streptozotocin injection in rats significantly protected against STZ-induced elevations in blood glucose levels which was correlated with a significant protection against pancreatic $\beta$-cell loss [54] In addition, RE increased serum insulin, $C$-peptide while decreased alanine aminotransferase (ALT) and aspartate aminotransferase (AST). Administration of dried rosemary leaves (5 g/100 g of diet) for approximately six weeks in STZ-induced diabetic and healthy Sprague-Dawley rats decreased the FPG, glycated hemoglobin (HbA1c), TC and TG and LDL levels in STZ- induced rats without effecting the plasma glucose levels or the lipid profile in the control group [55]. Oral administration of $\mathrm{RE}$ (200 mg/kg/day) with or without moderate intensity exercise training for eight weeks resulted in reduction of FPG and increased serum insulin levels in STZ-induced diabetic rats [56]. These effects were associated with an increased antioxidant activity including increase in serum CAT, SOD and GPx while decreasing malondialdehyde (MDA) [56]. In agreement, a more recent study showed that RA (120-200 mg/kg) dose-dependently decreased plasma glucose levels, and improved insulin sensitivity as supported by HOMA-IR analysis [57]. In STZ and high fat diet (HFD) induced diabetic rats, RA $(577 \mu \mathrm{g} / \mathrm{mL})$ decreased FPG levels and increased insulin levels without affecting liver glycogen levels [58]. These effects were associated with inhibition of intestinal brush border membrane levels of SGLT1 by 50\%, an active glucose transporter responsible for glucose absorption into the bloodstream [58]. Oral administration of RE (200 mg/kg/day) for six weeks protected against the reduced antioxidant status of diabetic rats with decreased GSH, CAT, and SOD; and increased lipid peroxidation marker MDA levels [59]. Assessment of renal biomarkers including serum creatinine, uric acid and urea levels showed that RE had renoprotective effects (Table 6) [59].

\section{Alloxan-Induced Diabetes Model}

In addition to the STZ-induced diabetic model, the alloxan-induced diabetes animal model is also used extensively. Alloxan causes diabetes by rapid depletion of pancreatic $\beta$-cells leading to inflammation and sustained hyperglycemia secondary to a reduction in insulin release into circulation. In alloxan-induced diabetic rabbits, ethanol RE (200 $\mathrm{mg} / \mathrm{kg}$ ) for one week led to a significant reduction in FPG and increase in insulin levels (Table 6) [60]. In contrast, another study indicated that intramuscular administration of volatile oil of RE (25 mg/kg) for 30, 60 and $120 \mathrm{~min}$ inhibited insulin release and increased blood glucose levels leading to hyperglycemia in normal and alloxan-induced diabetic rabbits [61]. In another study, oral administration of powdered RE added as $20 \%$ of diet or $20 \%$ aqueous RE for 45 days to alloxan-induced diabetic rats significantly decreased the FPG levels compared to control [62]. In addition, the treatment demonstrated to reduce alloxan-induced hepatocyte vacuolar degeneration, necrosis, small hemorrhages and dilatation of hepatic sinusoids indicating hepatoprotective effects [62]. Moreover, administration of RA (100-200 mg/kg) to alloxan-induced diabetic rats for eight weeks significantly inhibited glomerular hypertrophy, glomerular number loss and glomerulosclerosis compared with diabetic control indicating RA's renoprotective properties [63]. Administration of 250 and $500 \mathrm{mg} / \mathrm{kg} / \mathrm{day}$ of RE mixed with water (70\%) for 63 days in male rats did not affect serum blood glucose, TG, TC levels or body weight but testosterone levels, spermatogenesis, sperm density and motility were significantly 
decreased [64]. In addition, alanine aminotransferase (ALT) and aspartate aminotransferase (AST), enzymes released due to liver damage, were also decreased (Table 6).

\section{Genetically-Induced Diabetes Models}

Oral administration of CA (approximately $17 \mathrm{mg} / \mathrm{kg} /$ day) to obese leptin receptor deficient mice for five weeks resulted in significant protection against fat-induced fasting and non-fasting hyperglycemia, improved glucose tolerance as well as decreased serum insulin levels [65]. In addition, CA significantly inhibited weight gain, decreased regional areas of visceral fat, and prevented against fat accumulation in white adipose tissue and liver [65]. Moreover, animals supplemented with CA exhibited decreased serum levels of TG, TC, and ALT, as well as significantly decreased hepatic lipid storage [65]. In contrast, obese mice and their lean counterparts fed $0.5 \%$ ethanol extract of rosemary enriched with CA $(40 \%)$ incorporated in their standard chow for 64 days did not show significant differences in their glucose levels compared to control rats, although circulating insulin levels were found to be significantly decreased only in the lean rats (Table 6) [66]. Noteworthy, the plasma glucose levels in all animals were within normal physiological range with a non-significant, slight increase in obese counterparts. The study also demonstrated a significant inhibition of gastric lipase (GL) in the stomach and pancreatic lipase (PL) in small intestine of rats consuming the RE [66].

\section{Diet-Induced Diabetes Model}

Apart from animal models of genetic and chemically-induced obesity and T2DM, the effects of RE have been examined in dietary animal models of obesity and T2DM. Daily, dietary supplementation of RE (500 mg/ $\mathrm{kg}$ ) standardized to contain $20 \%$ CA for 16 weeks in mice that were started on a high-fat diet (HFD) as juveniles significantly protected against HFD-induced elevations in plasma glucose and TC levels compared with HFD control mice (Table 6) [34]. Notably, fasting insulinemia remained low during the length of the study and no significant differences were observed between the groups. Correlating with the observed reductions in total cholesterol levels, HFD mice supplemented with RE displayed significant decreases in fat mass and one to twofold increase in total fecal lipid content compared to HFD-fed control mice [34]. Additionally, another study indicated that administration CA $(20 \mathrm{mg} / \mathrm{kg})$ in $5-20 \mathrm{mg} / \mathrm{kg}$ olive oil loaded mice, significantly repressed the elevation of TG levels, prevented epididymal fat gain and inhibited pancreatic lipase activity [67]. Administration of $200 \mathrm{mg} / \mathrm{kg}$ of RE for 50 days in mice fed high fat diet, resulted in reduced body weight (b.w) and fat mass and increase of fecal lipid excretion, while hepatic triglyceride content was decreased [68]. Similarly, daily administration of aqueous RE $(100 \mathrm{mg} / \mathrm{kg} \mathrm{b.w})$ to high-cholesterol fed mice for 36 days resulted in significant decline in plasma TG, TC, LDL levels, while HDL levels were increased compared to control mice [69]. Furthermore, administration of aqueous RE (70-140 mg/kg b.w) and non-esterified phenolic RE (7-14 mg/ kg b.w) for four weeks resulted in significant reduction in TC and non-HDL levels compared to control [70]. High-fructose fed mice given daily dose of RA $(100 \mathrm{mg} / \mathrm{kg}$ b.w) for 60 days decreased fasting plasma glucose levels, improved glucose tolerance and reduced plasma insulin and glycated $\mathrm{HbA1c}$ levels (Table 6) [71]. 
Table 6. Anti-diabetic Effects of Rosemary Extract and its Main Polyphenolic Constituents: in vivo animal studies.

\begin{tabular}{|c|c|c|c|c|}
\hline Animal Model & Dose & Glucose & Other Measures & Reference \\
\hline \multicolumn{5}{|c|}{ Streptozotocin (STZ)-Induced Diabetic Model } \\
\hline $\begin{array}{l}\text { STZ-induced diabetic Swiss } \\
\text { albino mice }\end{array}$ & $\begin{array}{l}\text { Ad libitum }(10 \mathrm{~g} \text { leaves of } \\
\text { rosemary in } 1 \mathrm{~L} \text { boiling } \\
\text { water }) \text { for } 3 \text { months }\end{array}$ & $\begin{array}{l}\downarrow \text { FPG in healthy and } \\
\text { diabetic animals }\end{array}$ & $\begin{array}{l}\leftrightarrow \text { creatinine, urea } \\
\text { bilirubin, total albumin, } \\
\text { alkaline phosphatase }\end{array}$ & [49] \\
\hline $\begin{array}{l}\text { STZ-induced diabetic male } \\
\text { ddY mice }\end{array}$ & $\begin{array}{l}\text { aqueous and ethanolic RE } \\
20 \mathrm{mg} / \mathrm{kg} / \text { day }\end{array}$ & $\downarrow$ plasma glucose & $\downarrow \alpha$-glucosidase $(\mathrm{AGc})$ & [29] \\
\hline Male Wistar rats & $\begin{array}{l}\text { RA } 577 \mu \mathrm{g} / \mathrm{mL} \text { as drinking } \\
\text { fluid for } 14 \text { days }\end{array}$ & $\begin{array}{c}\downarrow \text { FPG } \\
\downarrow \text { OGTT } \\
\downarrow \text { HOMA-IR indices } \\
\uparrow \text { serum insulin }\end{array}$ & $\begin{array}{l}\downarrow \text { hepatic glycogen } \\
\text { content }\end{array}$ & [58] \\
\hline $\begin{array}{l}\text { STZ-induced diabetic male } \\
\text { albino rats }\end{array}$ & $\begin{array}{c}\text { aqueous RE, } \\
200 \mathrm{mg} / \mathrm{kg} / \text { day for } 3 \text { weeks }\end{array}$ & $\downarrow$ FPG & $\uparrow$ vitamin $C$ & {$[50]$} \\
\hline $\begin{array}{l}\text { STZ-induced diabetic male } \\
\text { albino rats }\end{array}$ & $\begin{array}{c}\text { aqueous RE } 4 \mathrm{~g} / \mathrm{kg} / \text { day for } \\
4 \text { weeks }\end{array}$ & $\downarrow$ FPG $(20 \%)$ & $\begin{array}{l}\downarrow \text { TC, TG, LDL } \\
\uparrow \text { HDL }\end{array}$ & [51] \\
\hline $\begin{array}{l}\text { STZ-induced diabetic male } \\
\text { albino rats }\end{array}$ & $\begin{array}{c}\text { aqueous RE, } \\
200 \mathrm{mg} / \mathrm{kg} / \text { day } 2 \text { weeks } \\
\text { prior and } 3 \text { weeks after STZ }\end{array}$ & $\downarrow \operatorname{FPG}(36.9 \%)$ & $\begin{array}{l}\downarrow \mathrm{TC}, \mathrm{TG}, \mathrm{LDL} \uparrow \mathrm{HDL} \\
\uparrow \text { hemoglobin }\end{array}$ & [52] \\
\hline $\begin{array}{l}\text { STZ-induced diabetic male } \\
\text { albino rats }\end{array}$ & $\begin{array}{c}\text { aqueous } \mathrm{RE}, 200 \\
\mathrm{mg} / \mathrm{kg} / \text { day for } 21 \text { days }\end{array}$ & $\downarrow$ FPG & $\begin{array}{l}\downarrow \mathrm{TC} \\
\downarrow \mathrm{TG} \\
\uparrow \mathrm{TAC}\end{array}$ & [53] \\
\hline $\begin{array}{l}\text { STZ-induced diabetic male } \\
\text { albino rats }\end{array}$ & $\begin{array}{c}\text { aqueous RE, } \\
200 \mathrm{mg} / \mathrm{kg} / \text { day } 2 \text { weeks } \\
\text { prior and } 3 \text { weeks after STZ }\end{array}$ & $\begin{array}{c}\downarrow \text { FPG in both groups } \\
\uparrow \text { serum insulin } \\
\uparrow C \text {-peptide } \\
\downarrow \beta \text {-cell loss }\end{array}$ & $\uparrow$ total albumin & {$[54]$} \\
\hline $\begin{array}{l}\text { STZ-induced diabetic male } \\
\text { Dawley rats }\end{array}$ & $\begin{array}{l}\text { Dried rosemary leaves } \\
\text { powder } 5 \mathrm{~g} / 100 \mathrm{~g} \text { of diet }\end{array}$ & $\begin{array}{c}\downarrow \text { FPG }(53.97 \%) \\
\downarrow \operatorname{HbA} 1 \mathrm{c}(24.56 \%)\end{array}$ & $\begin{array}{l}\downarrow \text { TG }(45.43 \%) \\
\downarrow \text { TC }(39.31 \%) \\
\downarrow \text { LDL }(33.89 \%)\end{array}$ & {$[55]$} \\
\hline Male albino Wistar rats & $\begin{array}{l}\text { aqueous RE } 200 \mathrm{mg} / \mathrm{kg} / \text { day } \\
\text { with/without moderate } \\
\text { intensity exercise training } \\
\text { for } 8 \text { weeks }\end{array}$ & $\begin{array}{r}\uparrow \\
\uparrow \text { Serum } C \\
\uparrow \operatorname{ser} \\
\downarrow\end{array}$ & $\begin{array}{l}\text { FPG } \\
\text { AT, SOD, GPx } \\
\text { n insulin } \\
\text { MDA }\end{array}$ & {$[56]$} \\
\hline $\begin{array}{l}\text { Sprague-Dawley male } \\
\text { albino rats }\end{array}$ & $\begin{array}{c}\text { aqueous RE } 200 \mathrm{mg} / \mathrm{kg} / \text { day } \\
\text { for } 6 \text { weeks }\end{array}$ & $\downarrow$ FPG & $\begin{array}{c}\uparrow \text { Serum CAT, SOD, GSH } \\
\downarrow \text { MDA } \\
\downarrow \text { urea, uric acid and } \\
\text { creatinine levels }\end{array}$ & {$[59]$} \\
\hline Male Wistar rats & $\begin{array}{c}\text { Intraperitoneal injection of } \\
\text { 120, } 160,200 \mathrm{mg} / \mathrm{kg} \text { RA for } \\
7 \text { days (acute) and } 28 \text { days } \\
\text { (chronic) }\end{array}$ & $\begin{array}{c}\downarrow \text { FPG } \\
\downarrow \text { OGTT } \\
\downarrow \text { HOMA-IR indices } \\
\uparrow \text { ITT } \\
\text { Normalized serum } \\
\text { insulin }\end{array}$ & $\begin{array}{c}\downarrow \text { hepatic PEPCK } \\
\text { expression/gluconeogenesis }\end{array}$ & {$[57]$} \\
\hline \multicolumn{5}{|c|}{ Alloxan-Induced Diabetes Model } \\
\hline $\begin{array}{l}\text { Alloxan-induced diabetic } \\
\text { rabbits }\end{array}$ & $\begin{array}{c}\text { ethanol RE, } 200 \mathrm{mg} / \mathrm{kg} \text { for } \\
6 \mathrm{~h} \text { (acute); for } 1 \text { week } \\
\text { (subacute) }\end{array}$ & $\begin{array}{c}\downarrow \text { FPG in healthy and } \\
\text { diabetic rabbits } \\
\uparrow \text { plasma insulin }\end{array}$ & $\begin{array}{l}\downarrow \mathrm{MDA} \\
\uparrow \mathrm{SOD} \\
\uparrow \mathrm{CAT}\end{array}$ & {$[60]$} \\
\hline $\begin{array}{l}\text { Alloxan-induced male } \\
\text { diabetic rabbits }\end{array}$ & $\begin{array}{l}\text { volatile RE, } 25 \mathrm{mg} / \mathrm{kg} \\
\text { intramuscular injection for } \\
30,60 \text { and } 120 \mathrm{~min}\end{array}$ & $\begin{array}{l}\uparrow \text { serum glucose } \\
\downarrow \text { serum insulin }\end{array}$ & & {$[61]$} \\
\hline $\begin{array}{l}\text { Alloxan-induced } \\
\text { Sprague-Dawley male } \\
\text { albino rats }\end{array}$ & $\begin{array}{c}20 \% \text { aqueous } \mathrm{RE} \text { and } 20 \% \\
\text { RE powdered food for } \\
45 \text { days }\end{array}$ & $\downarrow$ FPG & $\begin{array}{c}\downarrow \text { hepatocyte necrosis } \\
\downarrow \text { small hemorrhages } \\
\downarrow \text { hepatocyte degradation }\end{array}$ & [62] \\
\hline $\begin{array}{c}\text { Alloxan-induced } \\
\text { Sprague-Dawley } \\
\text { uninephrectomized rats }\end{array}$ & $\begin{array}{c}\text { RA } 100-200 \mathrm{mg} / \mathrm{kg} / \text { day for } \\
8 \text { weeks }\end{array}$ & & $\begin{array}{c}\downarrow \text { glomerulosclerosis } \\
\downarrow \text { creatinine and urea } \\
\downarrow \text { glomerular number } \\
\quad \downarrow \text { serum MDA }\end{array}$ & {$[63]$} \\
\hline $\begin{array}{c}\text { Male adult Sprague-Dawley } \\
\text { rats }\end{array}$ & $\begin{array}{c}70 \% \text { aqueous RE, } 250 \text { and } \\
500 \mathrm{mg} / \mathrm{kg} / \text { day for } 63 \text { days }\end{array}$ & $\leftrightarrow$ serum glucose & $\begin{array}{c}\leftrightarrow \text { body weight TG, TC } \\
\downarrow \text { alanine } \\
\text { aminotransferase (ALT) } \\
\downarrow \text { Aspartate } \\
\text { Aminotransferase (AST) } \\
\downarrow \text { spermatogenesis } \\
\downarrow \text { testosterone } \\
\downarrow \text { sperm motility }\end{array}$ & {$[64]$} \\
\hline
\end{tabular}


Table 6. Cont.

\begin{tabular}{|c|c|c|c|c|}
\hline Animal Model & Dose & Glucose & Other Measures & Reference \\
\hline \multicolumn{5}{|c|}{ Genetically-Induced Diabetes Models } \\
\hline Male ob/ob mice & $\begin{array}{c}\text { CA } 17 \mathrm{mg} / \mathrm{kg} / \text { day for } \\
5 \text { weeks }\end{array}$ & $\begin{array}{c}\downarrow \text { FPG }(18 \%) \\
\downarrow \text { OGTT glucose } \\
\downarrow \text { serum insulin }(47 \%)\end{array}$ & $\begin{array}{c}\downarrow \text { TC }(24 \%) \\
\downarrow \text { TG }(60 \%) \\
\downarrow \text { plasma FFA }(13 \%) \\
\downarrow \text { hepatic lipids } \\
\downarrow \text { ALT }(64 \%)\end{array}$ & [65] \\
\hline $\begin{array}{l}\text { Female Zucker lean }(\mathrm{fa} /+) \\
\text { and obese }(\mathrm{fa} / \mathrm{fa}) \text { rats }\end{array}$ & $\begin{array}{c}0.5 \% \mathrm{w} / \mathrm{w} \text { of aqueous } \mathrm{RE} \\
\text { enriched with CA for } \\
64 \text { days }\end{array}$ & $\begin{array}{c}\leftrightarrow \text { plasma glucose } \\
\downarrow \text { insulin levels in lean } \\
\text { animals }\end{array}$ & $\begin{array}{c}\text { Inhibited gastric lipase } \\
\text { activity in both lean }(70 \%) \\
\text { and obese animals (80\%) } \\
\downarrow \text { Serum total cholesterol, } \\
\text { TG, LDL } \\
\uparrow \text { HDL } \\
\end{array}$ & [66] \\
\hline \multicolumn{5}{|c|}{ Diet-Induced Diabetes Models } \\
\hline $\begin{array}{l}\text { HFD-treated male C57BL/6J } \\
\text { mice }\end{array}$ & $\begin{array}{c}\text { aqueous RE, } \\
\text { containing } 20 \% \mathrm{CA} \\
500 \mathrm{mg} / \mathrm{kg} / \text { day for } \\
16 \text { weeks }\end{array}$ & $\begin{array}{l}\downarrow \text { FPG }(72 \%) \\
\leftrightarrow \text { insulin }\end{array}$ & $\begin{array}{c}\downarrow \text { body weight } \\
\uparrow \text { fecal total lipid content } \\
(1-2 \text { fold }) \\
\downarrow \text { fat mass } \\
\downarrow \text { TC }(68 \%) \\
\leftrightarrow \mathrm{TG}\end{array}$ & [34] \\
\hline $\begin{array}{l}\text { HFD- (olive oil) treated male } \\
\text { ddY mice }\end{array}$ & $\begin{array}{c}\text { CA } 20 \mathrm{mg} / \mathrm{kg} \text { for } 14 \text { days } \\
\text { COH } 200 \mathrm{mg} / \mathrm{kg} \text { for } 14 \text { days }\end{array}$ & & $\begin{array}{c}\downarrow \text { body weight (7\%) } \\
\uparrow \text { epididymal fat } \\
\downarrow \text { pancreatic lipase (IC50 } \\
12 \text { and } 4.4 \mu \mathrm{g} / \mathrm{mL} \text { for CA } \\
\text { and COH respecively) }\end{array}$ & [67] \\
\hline $\begin{array}{l}\text { HFD-treated male C57BL/6J } \\
\text { mice }\end{array}$ & $\begin{array}{c}\text { ethanolic RE } 20 \text { or } \\
200 \mathrm{mg} / \mathrm{kg} / \text { day for } 50 \text { days }\end{array}$ & $\begin{array}{c}\leftrightarrow \text { FPG } \\
\leftrightarrow \text { glucose tolerance } \\
\leftrightarrow \text { insulin }\end{array}$ & $\begin{array}{c}\downarrow \text { body weight and fat } \\
\text { mass }(64 \% \text { and } 57 \%) \\
\downarrow \text { Hepatic TG }(39 \%) \\
\leftrightarrow \text { serum TG and TC } \\
\uparrow \text { fecal lipid excretion }\end{array}$ & [68] \\
\hline $\begin{array}{l}\text { Diet-induced HC female } \\
\text { BALB/c mice }\end{array}$ & $\begin{array}{c}\text { aqueous RE, } \\
100 \mathrm{mg} / \mathrm{kg} / \text { day for } 36 \text { days }\end{array}$ & & $\begin{array}{c}\downarrow \mathrm{TC}, \mathrm{TG}, \mathrm{LDL} \\
\uparrow \mathrm{HD}\end{array}$ & [69] \\
\hline Diet-induced HC Wistar rats & $\begin{array}{c}\text { aqueous RE, aqueous } \\
70-140 \mathrm{mg} / \mathrm{kg} / \text { day } \\
\text { RE non-esterified phenolic } \\
7-14 \mathrm{mg} / \mathrm{kg} / \text { day of for } \\
4 \text { weeks }\end{array}$ & & $\begin{array}{c}\downarrow \text { TC }(39.8 \%) \\
\downarrow \text { non-HDL }(44.4 \%)\end{array}$ & [70] \\
\hline $\begin{array}{l}\text { Fructose-fed Swiss albino } \\
\text { mice }\end{array}$ & $\begin{array}{l}\mathrm{RA} 100 \mathrm{mg} / \mathrm{kg} / \text { day for } \\
60 \text { days }\end{array}$ & $\begin{array}{c}\downarrow \text { FPG levels } \\
\downarrow \text { HbA1c } \\
\downarrow \text { OGTT glucose } \\
\downarrow \text { plasma insulin }\end{array}$ & $\begin{array}{l}\uparrow \text { diaphragm glucose } \\
\text { utilization }\end{array}$ & [71] \\
\hline
\end{tabular}

In addition to T2DM, type 1 diabetes mellitus (T1DM), an autoimmune disorder, is characterized by pancreatic $\beta$-cell destruction and hyperglycemia. Very limited number of studies investigating the effects of RE and its polyphenols in T1DM exist. A study demonstrated that co-treatment of RA and anti-CD154 monoclonal antibody improved islet allograft survival in a murine model [72]. In addition, the co-treatment resulted in fewer apoptotic cells and increased expression of insulin and glucagon [72]. Pancreatic islet transplantation is an area of intense research in the field of T1DM and immunosuppressants are used to reduce transplant rejection, however, they have detrimental/debilitating side effects. This study indicated that RE polyphenols improved outcome and minimized side effects when used in islet transplantation, however, further research is required to investigate their effectiveness in T1DM.

\section{Anti-Diabetic Effects of Rosemary Extract and Its Main Polyphenolic Constituents: In Vivo Human Studies}

In addition to numerous in vitro and in vivo studies, RE has been recently investigated in humans. Participants were randomly selected into three groups and treated with 2, 5 or $10 \mathrm{~g} /$ day of dried rosemary leaf powder for eight weeks [73] (Table 7). Blood samples were taken from participants before and after the study. FPG was decreased by $18.25 \%, 15.74 \%$ and $11.2 \%$ in the 10,5 and $2 \mathrm{~g} /$ day group, respectively. TC levels were significantly decreased by $34.48 \%$ in the $10 \mathrm{~g} /$ day group and 
$17.97 \%$ and $11.48 \%$ in the $5 \mathrm{~g} /$ day and $2 \mathrm{~g} /$ day groups, respectively. LDL cholesterol in this group was also significantly lowered by $32.28 \%$ in the $10 \mathrm{~g}$ /day treated group, and $28.46 \%$ and $15.58 \%$ in the $5 \mathrm{~g} /$ day and $2 \mathrm{~g} /$ day groups, respectively. Additionally, HDL cholesterol was increased by $22.91 \%$ in the $10 \mathrm{~g} /$ day group and $15.21 \%$ and $4.54 \%$ in the $5 \mathrm{~g} /$ day and $2 \mathrm{~g} /$ day groups, respectively. Furthermore, triglyceride levels were also decreased by $29.06 \%$ in the $10 \mathrm{~g} /$ day group and $21.3 \%$ and $14.97 \%$ in the $5 \mathrm{~g}$ /day and $2 \mathrm{~g}$ /day groups, respectively. In addition to the improvement in the overall lipid profile, rosemary powder seems to exhibit high antioxidant properties by decreasing MDA by $36.21 \%, 12.43 \%$ and $13.6 \%$ in the $10 \mathrm{~g} / \mathrm{day}, 5 \mathrm{~g} /$ day and $2 \mathrm{~g} /$ day treated groups, respectively. Glutathione reductase (GR) was decreased by $15.36 \%, 6.73 \%$, and $0.95 \%$ in the $10 \mathrm{~g} /$ day, $5 \mathrm{~g} / \mathrm{day}$ and $2 \mathrm{~g} /$ day treated groups respectively. Vitamin C indicated an increase by 19.93\%, 11.37\% and $8 \%$ in the $10 \mathrm{~g} /$ day, $5 \mathrm{~g} /$ day and $2 \mathrm{~g} /$ day treated groups, respectively. In addition, $\beta$ carotene levels increased by $45.23 \%, 33.33 \%$ and $7.5 \%$ in the $10 \mathrm{~g} / \mathrm{day}, 5 \mathrm{~g} /$ day and $2 \mathrm{~g} /$ day treated group. Additionally, there have been a few studies indirectly examining the effects of rosemary supplements with non-conclusive results. An observational, prospective, monocenter study examined the effect of 21 days of oral supplementation of aqueous RE (containing $77.7 \mathrm{mg}$ RE with $0.97 \mathrm{mg} \mathrm{COH}, 8.60 \mathrm{mg}$ CA, and $10.30 \mathrm{mg}$ RA) in twelve healthy young volunteers found a significant decrease in plasminogen activator-inhibitor-1 (PAI-1) levels suggesting that RE may have anti-inflammatory and anti-blood clotting activity in vivo [74]. Another observational study demonstrated that administration of RE and oleanolic acid (440 mg thrice a day for four weeks and additional $880 \mathrm{mg}$ twice a day for four weeks) in patients with osteoarthritis, fibromyalgia, and rheumatoid arthritis was protective against inflammatory rheumatic diseases, particularly in those with initial serum c-reactive protein (CRP) levels $>7.0 \mathrm{mg} / \mathrm{L}$ (Table 7) [75].

Table 7. Anti-diabetic Effects of Rosemary Extract and its Main Polyphenolic Constituents: in vivo human studies.

\begin{tabular}{|c|c|c|c|}
\hline Study Methodology & Treatment & Effect & Reference \\
\hline 48 healthy individuals & $\begin{array}{c}\text { Dry rosemary powder } \\
2,5 \text { or } 10 \mathrm{~g} / \text { day, for } 8 \text { weeks }\end{array}$ & $\begin{array}{c}\downarrow \text { FPG } \\
\downarrow \text { TC, } \downarrow \text { LDL } \downarrow \text { TG, } \uparrow \\
\text { HDL } \\
\downarrow \text { MDA, } \downarrow \text { GR } \\
\uparrow \text { vitamin C } \\
\uparrow \beta \text {-carotene }\end{array}$ & [73] \\
\hline 12 healthy, young volunteers & $\begin{array}{c}\text { RE } 77.7 \mathrm{mg} \\
\text { COH } 0.97 \mathrm{mg} \\
\text { CA } 8.6 \mathrm{mg} \\
\text { RA } 10.30 \mathrm{mg} \text { for } 21 \text { days }\end{array}$ & $\downarrow$ PAI-1 & [74] \\
\hline $\begin{array}{l}72 \text { patients with rheumatic } \\
\text { disease including osteoarthritis } \\
\text { (OA), rheumatoid arthritis, } \\
\text { fibromyalgia (FM) }\end{array}$ & $\begin{array}{l}\text { Meta050 compound (RE, oleanolic acid } \\
\text { and reduced iso-alpha-acids) } \\
440 \mathrm{mg} / \text { day for } 4 \text { weeks } 3 \text { times per day } \\
880 \mathrm{mg} / \text { day for } 4 \text { weeks } 2 \text { times per day }\end{array}$ & $\begin{array}{l}\downarrow \downarrow \text { CRP } \\
\downarrow \text { arthritis pain scores } \\
\leftrightarrow \text { fibromyalgia scores }\end{array}$ & [75] \\
\hline
\end{tabular}

\section{Conclusions}

Rosemary extract and the rosemary extract polyphenols carnosic acid and rosmarinic acid have been shown to have insulin-like effects in insulin target cells in vitro and to exert significant anti-diabetic effects in different animal models of T2DM in vivo. Rosemary extract and rosemary extract polyphenols exhibit protective properties against hyperlipidemia and hyperglycemia in genetic, chemically-induced and dietary animal models of obesity and T2DM. These promising findings from in vivo animal studies suggest a potential to use RE and its polyphenolic constituents towards the management of blood glucose levels and diabetes. However, more studies are warranted to fill the gaps in research. On the one end of the research spectrum, in vitro studies are needed to delineate the direct effects of RE and its polyphenolic constituents in specific cell and tissue types and thereby ascertain their mechanism of action. On the other end, clinical trials are warranted to examine the 
effects of RE and its polyphenolic constituents directly in humans. Furthermore, more research is needed to address questions surrounding bioavailability of RE and its polyphenolic components, and therapeutic dosage ranges relevant in humans.

Acknowledgments: This work was supported by a Natural Sciences and Engineering Research Council of Canada (NSERC) and by a Brock University Advancement Fund (BUAF) grant to E.T. A Brock Library Open Access Publishing Fund was awarded to HS and used towards publication fee payment.

Author Contributions: E.T. formulated the review topic. M.N. and E.T. wrote the majority of the manuscript. F.V. and H.S. contributed to the writing of the manuscript, table and figure preparation. All authors read and approved the final manuscript.

Conflicts of Interest: The authors declare no conflict of interest.

\section{Abbreviations}

\begin{tabular}{|c|c|}
\hline ALP & Alkaline phosphatase \\
\hline ALT & Alanine aminotransferase \\
\hline AST & Aspartate transaminase \\
\hline CA & Carnosic acid \\
\hline CAT & Catalase \\
\hline $\mathrm{C} / \mathrm{EBP} \alpha$ & CCAAT-enhancer binding proteins, \\
\hline $\mathrm{COH}$ & Carnosol \\
\hline CRP & C-reactive protein \\
\hline DDP-4 & Dipeptidyl peptide 4 \\
\hline DGAT1 & Diacylglycerol acyltransferase 1 \\
\hline ERK & Extracellular signal-regulated kinase \\
\hline FDA & Food and Drug Administration \\
\hline FFA & Free fatty acids \\
\hline FM & Fibromyalgia \\
\hline FPG & Fasting plasma glucose \\
\hline GL & Gastric lipase \\
\hline GLP-1 & Glucagon-like peptide 1 \\
\hline GPDH & Glycerol-3-phosphate dehydrogenase \\
\hline GPx & Glutathione peroxidase \\
\hline GSH & Glutathione \\
\hline GU & Glucose uptake \\
\hline HSL & Hormone sensitive lipase \\
\hline HDL & High-density lipoprotein \\
\hline HFD & High-fat diet \\
\hline $\mathrm{HbA1c}$ & Glycated hemoglobin \\
\hline IDF & International Diabetes Federation \\
\hline ITT & Insulin tolerance test \\
\hline LDL & Low-density-lipoprotein \\
\hline MCP-1 & Monocyte chemoattract protein 1 \\
\hline MDA & Malondialdehyde \\
\hline MUFA & Monounsaturated fatty acids \\
\hline NF-kB & Nuclear factor kappa-light-chain-enhancer of activated B cells \\
\hline $\mathrm{OA}$ & Osteoarthritis \\
\hline OGTT & Oral glucose tolerance test \\
\hline PAI-1 & Plasminogen activator inhibitor-1 \\
\hline PEPCK & Phosphoenolypyruvate carboxykinase \\
\hline PL & Pancreatic lipase \\
\hline PPAR & Peroxisome proliferator activated receptor, \\
\hline RA & Rosmarinic acid \\
\hline RE & Rosemary extract \\
\hline ROS & Reactive oxygen species \\
\hline
\end{tabular}




$\begin{array}{ll}\text { SCD1 } & \text { Stearoyl coA desaturase } 1 \\ \text { SFA } & \text { Saturated fatty acids } \\ \text { SGLT1 } & \text { Sodium glucose cotransporters 1 } \\ \text { SGLT2 } & \text { Sodium-glucose cotransporter 2, } \\ \text { SOD } & \text { Superoxide dismutase } \\ \text { SREBP1 } & \text { Sterol regulatory element binding protein 1 } \\ \text { STZ } & \text { Streptozotocin } \\ \text { T1DM } & \text { Type 1 diabetes mellitus } \\ \text { T2DM } & \text { Type 2 diabetes mellitus } \\ \text { TC } & \text { Total cholesterol } \\ \text { TG } & \text { Triglycerides } \\ \text { TNF } \alpha & \text { Tumor necrosis factor } \alpha\end{array}$

\section{References}

1. Tripathy, D.; Chavez, A.O. Defects in insulin secretion and action in the pathogenesis of type 2 diabetes mellitus. Curr. Diabete Rep. 2010, 10, 184-191. [CrossRef] [PubMed]

2. Shaw, J.E.; Sicree, R.A.; Zimmet, P.Z. Diabetes atlas: Global estimates of the prevalence of diabetes for 2010 and 2030. Diabetes Res. Clin. Pract. 2010, 87, 4-14. [CrossRef] [PubMed]

3. Tran, L.; Zielinski, A.; Roach, A.H.; Jende, J.A.; Householder, A.M.; Cole, E.E.; Atway, S.A.; Amornyard, M.; Accursi, M.L.; Shieh, S.W.; et al. Pharmacologic treatment of type 2 diabetes oral medications. Ann. Pharmacother. 2015, 49, 540-556. [CrossRef] [PubMed]

4. DeFronzo, R.; Fleming, G.A.; Chen, K.; Bicsak, T.A. Metformin-associated lactic acidosis: Current perspectives on causes and risk. Metabolism 2016, 65, 20-29. [CrossRef] [PubMed]

5. Okayasu, S.; Kitaichi, K.; Hori, A.; Suwa, T.; Horikawa, Y.; Yamamoto, M.; Takeda, J.; Itoh, Y. The evaluation of risk factors associated with adverse drug reactions by metformin in type 2 diabetes mellitus. Biol. Pharm. Bull. 2012, 35, 933-937. [CrossRef] [PubMed]

6. Wu, S.; Hopper, I.; Skiba, M.; Krum, H. Dipeptidyl peptidase-4 inhibitors and cardiovascular outcomes: Meta-analysis of randomized clinical trials with 55,141 participants. Cardiovasc. Ther. 2014, 32, 147-158. [CrossRef] [PubMed]

7. Forsmark, C.E. Incretins, Diabetes, pancreatitis and pancreatic cancer: What the GI specialist needs to know. Pancreatollogy 2016, 16, 10-13. [CrossRef] [PubMed]

8. Dailey, G.E. Empagliflozin: A new treatment option for patients with type 2 diabetes mellitus. Drugs Today 2015, 51, 519-535. [CrossRef] [PubMed]

9. Center for Drug Evaluation and Research Drug Safety and Availability. FDA Drug Safety Communication: FDA Revises Labels of SGLT2 Inhibitors for Diabetes to Include Warnings about too Much Acid in the Blood and Serious Urinary Tract Infections. Available online: http:/ / www.fda.gov/Drugs/DrugSafety/ ucm475463.htm (accessed on 10 April 2016).

10. Bent, S. Herbal medicine in the United States: Review of efficacy, safety, and regulation-Grand rounds at University of California, San Francisco Medical Center. J. Gen. Intern. Med. 2008, 23, 854-859. [CrossRef] [PubMed]

11. Aguilar, F.; Herman, A.; Barlow, S.; Castle, L.; Crebelli, R.; Dekant, W.; Engel, K. Use of rosemary extracts as a food additive-scientific opinion of the panel on food additives, flavourings, processing aids and materials in contact with food. EFSA J. 2008, 6, 721. [CrossRef]

12. Schwarz, K. Phenolic Diterpenes from Rosemary and Sage; CRC: Boca Raton, FL, USA, 2002.

13. González-Vallinas, M.; Reglero, G.; Ramírez de Molina, A. Rosemary (Rosmarinus officinalis L.) extract as a potential complementary agent in anticancer therapy. Nutr. Cancer 2015, 67, 1223-1231. [CrossRef] [PubMed]

14. Sedighi, R.; Zhao, Y.; Yerke, A.; Sang, S. Preventive and protective properties of rosemary (Rosmarinus officinalis L.) in obesity and diabetes mellitus of metabolic disorders: A brief review. Curr. Opin. Food Sci. 2015, 2, 58-70. [CrossRef]

15. Hassani, F.V.; Shirani, K.; Hosseinzadeh, H. Rosemary (Rosmarinus officinalis) as a potential therapeutic plant in metabolic syndrome: A review. Naunyn-Schmiedebergs Arch. Pharmacol. 2016, 389, 931-949. [CrossRef] [PubMed] 
16. De Raadt, P.; Wirtz, S.; Vos, E.; Verhagen, H. Short review of extracts of rosemary as a food additive. Eur. J. Nutr. Food Saf. 2015, 5, 126-137. [CrossRef] [PubMed]

17. Ulbricht, C.; Abrams, T.; Brigham, A.; Ceurvels, J.; Clubb, J.; Curtiss, W.; Kirkwood, C.; Giese, N.; Hoehn, K.; Iovin, R.; et al. An evidence-based systematic review of rosemary (Rosmarinus officinalis) by the natural standard research collaboration. J. Diet. Suppl. 2010, 7, 351-413. [CrossRef] [PubMed]

18. Ho, C.T.; Wang, M.; Wei, G.J.; Huang, T.C.; Huang, M.T. Chemistry and antioxidative factors in rosemary and sage. BioFactors 2000, 13, 161-166. [CrossRef] [PubMed]

19. Al-Sereiti, M.R.; Abu-Amer, K.M.; Sen, P. Pharmacology of rosemary (Rosmarinus officinalis Linn.) and its therapeutic potentials. Indian J. Exp. Biol. 1999, 37, 124-130. [PubMed]

20. Zhang, Y.; Smuts, J.P.; Dodbiba, E.; Rangarajan, R.; Lang, J.C.; Armstrong, D.W. Degradation study of carnosic acid, carnosol, rosmarinic acid, and rosemary extract (Rosmarinus officinalis L.) assessed using HPLC. J. Agric. Food Chem. 2012, 60, 9305-9314. [CrossRef] [PubMed]

21. Hossain, M.B.; Rai, D.K.; Brunton, N.P.; Martin-Diana, A.B.; Barry-Ryan, C. Characterization of phenolic composition in Lamiaceae spices by LC-ESI-MS/MS. J. Agric. Food Chem. 2010, 58, 10576-10581. [CrossRef] [PubMed]

22. Vallverdú-Queralt, A.; Regueiro, J.; Martínez-Huélamo, M.; Rinaldi Alvarenga, J.F.; Leal, L.N.; Lamuela-Raventos, R.M. A comprehensive study on the phenolic profile of widely used culinary herbs and spices: Rosemary, thyme, oregano, cinnamon, cumin and bay. Food Chem. 2014, 154, 299-307. [CrossRef] [PubMed]

23. Kontogianni, V.G.; Tomic, G.; Nikolic, I.; Nerantzaki, A.A.; Sayyad, N.; Stosic-Grujicic, S.; Stojanovic, I.; Gerothanassis, I.P.; Tzakos, A.G. Phytochemical profile of Rosmarinus officinalis and Salvia officinalis extracts and correlation to their antioxidant and anti-proliferative activity. Food Chem. 2013, 136, 120-129. [CrossRef] [PubMed]

24. Ferlemi, A.-V.; Katsikoudi, A.; Kontogianni, V.G.; Kellici, T.F.; Iatrou, G.; Lamari, F.N.; Tzakos, A.G.; Margarity, M. Rosemary tea consumption results to anxiolytic- and anti-depressant-like behavior of adult male mice and inhibits all cerebral area and liver cholinesterase activity; phytochemical investigation and in silico studies. Chem. Biol. Interact. 2015, 237, 47-57. [CrossRef] [PubMed]

25. Genena, A.K.; Hense, H.; Smania Junior, A.; Machado de Souza, S. Rosemary (Rosmarinus officinalis)—A study of the composition, antioxidant and antimicrobial activities of extracts obtained with supercritical carbon dioxide. Cienc. Tecnol. Aliment. 2008, 28, 463-469. [CrossRef]

26. Moreno, S.; Scheyer, T.; Romano, C.S.; Vojnov, A.A. Antioxidant and antimicrobial activities of rosemary extracts linked to their polyphenol composition. Free Radic. Res. 2006, 40, 223-231. [CrossRef] [PubMed]

27. Xiao, J.; Kai, G.; Yamamoto, K.; Chen, X. Advance in dietary polyphenols as $\alpha$-glucosidases inhibitors: A review on structure-activity relationship aspect. Crit. Rev. Food Sci. Nutr. 2013, 53, 818-836. [CrossRef] [PubMed]

28. Funke, I.; Melzig, M.F. Traditionally used plants in diabetes therapy: Phytotherapeutics as inhibitors of alpha-amylase activity. Rev. Bras. Farmacogn. 2006, 16, 1-5. [CrossRef]

29. Koga, K.; Shibata, H.; Yoshino, K.; Nomoto, K. Effects of $50 \%$ ethanol extract from rosemary (Rosmarinus officinalis) on $\alpha$-glucosidase inhibitory activity and the elevation of plasma glucose level in rats, and its active compound. J. Food Sci. 2006, 71, S507-S512. [CrossRef]

30. McCue, P.P.; Shetty, K. Inhibitory effects of rosmarinic acid extracts on porcine pancreatic amylase in vitro. Asia Pac. J. Clin. Nutr. 2004, 13, 101-106. [PubMed]

31. Bower, A.M.; Real Hernandez, L.M.; Berhow, M.A.; de Mejia, E.G. Bioactive compounds from culinary herbs inhibit a molecular target for type 2 diabetes management, dipeptidyl peptidase IV. J. Agric. Food Chem. 2014, 62, 6147-6158. [CrossRef] [PubMed]

32. Reis, P.; Holmberg, K.; Watzke, H.; Leser, M.E.; Miller, R. Lipases at interfaces: A review. Adv. Colloid Interface Sci. 2009, 147, 237-250. [CrossRef] [PubMed]

33. Bustanji, Y.; Issa, A.; Mohammad, M.; Hudaib, M.; Tawah, K.; Alkhatib, H.; Almasri, I.; Al-Khalidi, B. Inhibition of hormone sensitive lipase and pancreatic lipase by Rosmarinus officinalis extract and selected phenolic constituents. J. Med. Plants Res. 2010, 4, 2235-2242. [CrossRef]

34. Ibarra, A.; Cases, J.; Roller, M.; Chiralt-Boix, A.; Coussaert, A.; Ripoll, C. Carnosic-acid rich rosemary (Rosmarinus officinalis L.) leaf extract limits weight gain and improves cholesterol levels and glycaemia in mice on a high-fat diet. Br. J. Nutr. 2011, 106, 1182-1189. [CrossRef] [PubMed] 
35. Cui, L.; Kim, M.O.; Seo, J.H.; Kim, I.S.; Kim, N.Y.; Lee, S.H.; Park, J.; Kim, J.; Lee, H.S. Abietane diterpenoids of Rosmarinus officinalis and their diacylglycerol acyltransferase-inhibitory activity. Food Chem. 2012, 132, 1775-1780. [CrossRef]

36. Yun, Y.S.; Noda, S.; Shigemori, G.; Kuriyama, R.; Takahashi, S.; Umemura, M.; Takahashi, Y.; Inoue, H. Phenolic diterpenes from rosemary suppress cAMP Responsiveness of gluconeogenic gene promoters. Phytother. Res. 2013, 27, 906-910. [CrossRef] [PubMed]

37. Tu, Z.; Moss-Pierce, T.; Ford, P.; Jiang, T. Rosemary (Rosmarinus officinalis L.) Extract regulates glucose and lipid metabolism by activating AMPK and PPAR pathways in Hep G2 cells. J. Agric. Food Chem. 2013, 61, 2803-2810. [CrossRef] [PubMed]

38. Wang, T.; Takikawa, Y.; Tabuchi, T.; Satoh, T.; Kosaka, K.; Suzuki, K. Carnosic acid (CA) prevents lipid accumulation in hepatocytes through the EGFR/MAPK pathway. J. Gastroenterol. 2012, 47, 805-813. [CrossRef] [PubMed]

39. Renzulli, C.; Galvano, F.; Pierdomenico, L.; Speroni, E.; Guerra, M.C. Effects of rosmarinic acid against aflatoxin B1 and ochratoxin-a-induced cell damage in a human hepatoma cell line (Hep G2). J. Appl. Toxicol. 2004, 24, 289-296. [CrossRef] [PubMed]

40. Takahashi, T.; Tabuchi, T.; Tamaki, Y.; Kosaka, K.; Takikawa, Y.; Satoh, T. Carnosic acid and carnosol inhibit adipocyte differentiation in mouse 3T3-L1 cells through induction of phase 2 enzymes and activation of glutathione metabolism. Biochem. Biophys. Res. Commun. 2009, 382, 549-554. [CrossRef] [PubMed]

41. Gaya, M.; Repetto, V.; Toneatto, J.; Anesini, C.; Piwien-Pilipuk, G.; Moreno, S. Antiadipogenic effect of carnosic acid, a natural compound present in Rosmarinus officinalis, is exerted through the C/EBPs and PPAR pathways at the onset of the differentiation program. Biochim. Biophys. Acta-Gen. Subj. 2013, 1830, 3796-3806. [CrossRef] [PubMed]

42. Babish, J.G.; Pacioretty, L.M.; Bland, J.S.; Minich, D.M.; Hu, J.; Tripp, M.L. Antidiabetic screening of commercial botanical products in 3T3-L1 adipocytes and db/db mice. J. Med. Food 2010, 13, 535-547. [CrossRef] [PubMed]

43. Park, M.-Y.; Sung, M.-K. Carnosic Acid Inhibits Lipid Accumulation in 3T3-L1 Adipocytes Through Attenuation of Fatty Acid Desaturation. J. Cancer Prev. 2015, 20, 41-49. [CrossRef] [PubMed]

44. Park, M.-Y.; Mun, S.T. Carnosic acid inhibits TLR4-MyD88 signaling pathway in LPS-stimulated 3T3-L1 adipocytes. Nutr. Res. Pract. 2014, 8, 516-520. [CrossRef] [PubMed]

45. Naimi, M.; Tsakiridis, T.; Stamatatos, T.C.; Alexandropoulos, D.I.; Tsiani, E. Increased skeletal muscle glucose uptake by rosemary extract through AMPK activation. Appl. Physiol. Nutr. Metab. 2015, 40, 407-413. [CrossRef] [PubMed]

46. Lipina, C.; Hundal, H.S. Carnosic acid stimulates glucose uptake in skeletal muscle cells via a PME-1/PP2A/PKB signalling axis. Cell. Signal. 2014, 26, 2343-2349. [CrossRef] [PubMed]

47. Naimi, M.; Vlavcheski, F.; Murphy, B.; Hudlicky, T.; Tsiani, E. Carnosic acid as a component of rosemary extract stimulates skeletal muscle cell glucose uptake via AMPK activation. Clin. Exp. Pharmacol. Physiol. 2016. [CrossRef] [PubMed]

48. Szkudelski, T. The mechanism of alloxan and streptozotocin action in B cells of the rat pancreas. Physiol. Res. 2001, 50, 537-546. [PubMed]

49. Erenmemisoglu, A.; Saraymen, R.; Ustun, S. Effect of a Rosmarinus officinalis leave extract on plasma glucose levels in normoglycaemic and diabetic mice. Pharmazie 1997, 52, 645-646. [PubMed]

50. Khalil, O.; Ramadan, K.; Danial, E.; Alnahdi, H.; Ayaz, N. Antidiabetic activity of Rosmarinus officinalis and its relationship with the antioxidant property. Afr. J. Pharm. Pharmacol. 2012, 6, 1031-1036.

51. Al-Jamal, A.-R.; Alqadi, T. Effects of rosemary (Rosmarinus officinalis) on lipid profile of diabetic rats. Jordan J. Biol. Sci. 2011, 4, 199-203.

52. Alnahdi, H.S. Effect of Rosmarinus officinalis extract on some cardiac enzymes of streptozotocin-induced diabetic rats. J. Health Sci. 2012, 2, 33-37. [CrossRef]

53. Emam, M.A. Comparative evaluation of anti-diabetic activity of Rosmarinus officinailis L. and Chamomile recutita in streptozotocin induced diabetic rats. Agric. Biol. J. N. Am. 2012, 3, 247-252.

54. Ramadan, K.S.; Khalil, O.A.; Danial, E.N.; Alnahdi, H.S.; Ayaz, N.O. Hypoglycemic and hepatoprotective activity of Rosmarinus officinalis extract in diabetic rats. J. Physiol. Biochem. 2013, 69, 779-783. [CrossRef] [PubMed] 
55. Soliman, G.Z.A. Effect of Rosmarinus officinalis on lipid profile of streptozotocin-induced diabetic rats. Egypt. J. Hosp. Med. 2013, 53, 809-815. [CrossRef]

56. Nazem, F.; Farhangi, N.; Neshat-Gharamaleki, M. Beneficial effects of endurance exercise with Rosmarinus officinalis labiatae leaves extract on blood antioxidant enzyme activities and lipid peroxidation in streptozotocin-induced diabetic rats. Can. J. Diabetes 2015, 39, 229-234. [CrossRef] [PubMed]

57. Runtuwene, J.; Cheng, K.-C.; Asakawa, A.; Amitani, H.; Amitani, M.; Morinaga, A.; Takimoto, Y.; Kairupan, B.H.R.; Inui, A. Rosmarinic acid ameliorates hyperglycemia and insulin sensitivity in diabetic rats, potentially by modulating the expression of PEPCK and GLUT4. Drug Des. Dev. Ther. 2016, 10, 2193-2202. [CrossRef]

58. Azevedo, M.F.; Lima, C.F.; Fernandes-Ferreira, M.; Almeida, M.J.; Wilson, J.M.; Pereira-Wilson, C. Rosmarinic acid, major phenolic constituent of Greek sage herbal tea, modulates rat intestinal SGLT1 levels with effects on blood glucose. Mol. Nutr. Food Res. 2011, 55 (Suppl. 1), S15-S25. [CrossRef] [PubMed]

59. Header, E.; Elsawy, N.; El-boshy, M.; Basalamah, M.; Mubarak, M.; Hadda, T. POM analyses of constituents of Rosmarinus officinalis and their synergistic effect in experimental diabetic rats. J. Bioanal. Biomed. 2015, 7, 18-23. [CrossRef]

60. Bakırel, T.; Bakırel, U.; Keleş, O.Ü.; Ülgen, S.G.; Yardibi, H. In vivo assessment of antidiabetic and antioxidant activities of rosemary (Rosmarinus officinalis) in alloxan-diabetic rabbits. J. Ethnopharmacol. 2008, 116, 64-73. [CrossRef] [PubMed]

61. Alhader, A.; Hasan, Z.; Aqel, M. Hyperglycemic and insulin release inhibitory effects of Rosmarinus Officinalis. J. Ethnopharmacol. 1994, 43, 217-221. [CrossRef]

62. Kensara, O.; ElSawy, N.; Altaf, F.; Header, E. Hypoglycemic and hepato-protective effects of Rosmarinus officinalis in experimental diabetic Rats. UQU Med. J. 2010, 1, 98-113.

63. Tavafi, M.; Ahmadvand, H.; Khalatbari, A.; Tamjidipoor, A. Rosmarinic acid ameliorates diabetic nephropathy in uninephrectomized diabetic rats. Iran. J. Basic Med. Sci. 2011, 14, 275-283.

64. Nusier, M.K.; Bataineh, H.N.; Daradkah, H.M. Adverse effects of rosemary (Rosmarinus officinalis L.) on reproductive function in adult male rats. Exp. Biol. Med. 2007, 232, 809-813.

65. Wang, T.; Takikawa, Y.; Satoh, T.; Yoshioka, Y.; Kosaka, K.; Tatemichi, Y.; Suzuki, K. Carnosic acid prevents obesity and hepatic steatosis in ob/ob mice. Hepatol. Res. 2011, 41, 87-92. [CrossRef] [PubMed]

66. Vaquero, M.R.; Yáñez-Gascón, M.-J.; Villalba, R.G.; Larrosa, M.; Fromentin, E.; Ibarra, A.; Roller, M.; Tomás-Barberán, F.; de Gea, J.C.E.; García-Conesa, M.-T. Inhibition of gastric lipase as a mechanism for body weight and plasma lipids reduction in zucker rats fed a rosemary extract rich in carnosic acid. PLoS ONE 2012, 7, e39773. [CrossRef] [PubMed]

67. Ninomiya, K.; Matsuda, H.; Shimoda, H.; Norihisa, N.; Kasajima, N.; Yoshino, T.; Morikawa, T.; Yoshikawa, M. Carnosic acid, a new class of lipid absorption inhibitor from sage. Bioorg. Med. Chem. Lett. 2004, 14, 1943-1946. [CrossRef] [PubMed]

68. Harach, T.; Aprikian, O.; Monnard, I.; Moulin, J.; Membrez, M.; Beolor, J.-C.; Raab, T.; Mace, K.; Darimont, C. Rosemary (Rosmarinus officinalis L.) leaf extract limits weight gain and liver steatosis in mice fed a high-fat diet. Planta Med. 2010, 76, 566-571. [CrossRef] [PubMed]

69. Al Sheyab, F.M.; Abuharfeil, N.; Salloum, L.; Hani, R.B.; Awad, D.S. The effect of rosemary (Rosmarinus officinalis. L) plant extracts on the immune response and lipid profile in mice. J. Biol. Life Sci. 2011, 3. [CrossRef]

70. Afonso, M.S.; de O Silva, A.M.; Carvalho, E.B.; Rivelli, D.P.; Barros, S.B.; Rogero, M.M.; Lottenberg, A.M.; Torres, R.P.; Mancini-Filho, J. Phenolic compounds from rosemary (Rosmarinus officinalis L.) attenuate oxidative stress and reduce blood cholesterol concentrations in diet-induced hypercholesterolemic rats. Nutr. Metab. 2013, 10, 19. [CrossRef] [PubMed]

71. Vanithadevi, B.; Anuradha, C.V. Effect of rosmarinic acid on insulin sensitivity, glyoxalase system and oxidative events in liver of fructose-fed mice. Int. J. Diabetes Metab. 2008, 16, 35-44.

72. Jung, D.Y.; Kim, E.Y.; Joo, S.Y.; Park, J.B.; Moon, C.; Kim, S.H.; Sim, E.Y.; Joh, J.W.; Kwon, C.H.; Kwon, G.Y.; et al. Prolonged survival of islet allografts in mice treated with rosmarinic acid and anti-CD154 antibody. Exp. Mol. Med. 2008, 40,1-10. [CrossRef] [PubMed]

73. Labban, L.; Mustafa, U.E.-S.; Ibrahim, Y.M. The Effects of Rosemary (Rosmarinus officinalis) Leaves Powder on Glucose Level, Lipid Profile and Lipid Perodoxation. Int. J. Clin. Med. 2014, 5, 297-304. [CrossRef] 
74. Sinkovic, A.; Suran, D.; Lokar, L.; Fliser, E.; Skerget, M.; Novak, Z.; Knez, Z. Rosemary extracts improve flow-mediated dilatation of the brachial artery and plasma PAI-1 activity in healthy young volunteers. Phytother. Res. PTR 2011, 25, 402-407. [CrossRef] [PubMed]

75. Lukaczer, D.; Darland, G.; Tripp, M.; Liska, D.; Lerman, R.H.; Schiltz, B.; Bland, J.S. A pilot trial evaluating Meta050, a proprietary combination of reduced iso-alpha acids, rosemary extract and oleanolic acid in patients with arthritis and fibromyalgia. Phytother. Res. PTR 2005, 19, 864-869. [CrossRef] [PubMed]

(C) 2017 by the authors. Licensee MDPI, Basel, Switzerland. This article is an open access article distributed under the terms and conditions of the Creative Commons Attribution (CC BY) license (http:/ / creativecommons.org/licenses/by/4.0/). 